\title{
OVERWEIGHT AND ITS RELATIONSHIP WITH DURATION OF BREASTFEEDING IN PRESCHOOLERS
}

\author{
Karen Marianne Soares Caldeira1, José Maria Pacheco de Souza², \\ Sonia Buongermino de Souza ${ }^{3}$
}

DOI: http://dx.doi.org/10.7322/jhgd.96786

\begin{abstract}
Introduction: obesity is increasing significantly, even in children and adolescents. Breastfeeding has been implicated as a preventive factor of many diseases and in recent years the protective role of breastfeeding against childhood obesity has been observed. Objective: to investigate the prevalence of overweight and its relationship with breastfeeding in children aged 48-60 months. Methods: across-sectional study was conducted involving collection of anthropometric data of children aged 48-60 months from public schools of a city located in Minas Gerais-MG, Brazil, for calculation of body mass index (BMI) and nutritional classification. Data on breastfeeding duration and current feeding were also collected, as well as demographic and socioeconomic variables. Overweight was considered the outcome variable. The main explanatory variable was breastfeeding while the control variables were current feeding and demographic and socioeconomic variables. The relationship between the outcome and explanatory variables was assessed using Poisson regression. Results: the prevalence of overweight children was 9.6\%. Exclusive breastfeeding (EBF) for upto 6 months or loger was given to $32.11 \%$ of children. The study showed a positive relationship between the presence of EBF and absence of overweight in children aged 48-60 months for the category EBF for 6 months or longer. A similar relationship was not found for complemented breastfeeding. Conclusions: the prevalence of overweight children in the study (9.6\%) was higher than the national average $(7 \%)$. Exclusive breastfeeding for 6 months or longer was associated with absence of overweight and complemented breastfeeding was not associated with children's weight.
\end{abstract}

Key words: breast-feeding, child obesity.

\section{INTRODUCTION}

Obesity, a disease characterized by the accumulation of excess body fats deleterious to health, is growing in prevalence worldwide and also affecting the pediatric population ${ }^{1}$.

In Brazil, according to the 2006 National Survey on Demography and Health (PNDS) which assessed the nutritional status of children up to age of 5 years, $7.3 \%$ had over the recommended weightfor-height while around $7 \%$ had stunted height-forage, a marker of undernutrition ${ }^{2}$.

The leading causes of obesity, according to the World Health Organization (WHO) ${ }^{1}$, are increased consumption of foods rich in fat, salt and sugar and reduced time practicing physical activity, allied with changes in modes of transportation and high levels of urbanization of countries.
Numerous studies have been conducted to ascertain the variables associated with this imbalance in food intake. One such variable is the influence of the social environment in which the individual lives, a factor which shapes beliefs, habits of the society, place of abode, schooling and access to food ${ }^{3,4}$.

Another cause described by the $\mathrm{WHO}^{1}$ is reduced levels of physical activity, i.e. increased sedentarism, driven by the current urban lifestyle and level of violence in the streets, leading to children spending longer periods watching television ${ }^{4}$.

Socioeconomic conditions also influence the prevalence of obesity. According to the WHO, transport policies, urban planning, marketing, heath, agriculture, distribution of processed foods and education all comprise socioeconomic

1 Supervisão de Vigilância em Saúde Freguesia do Ó/Brasilândia - Secretaria da Saúde da Prefeitura Municipal de São Paulo. - São Paulo, SP.

2 Departamento de Epidemiologia da Faculdade de Saúde Pública - USP. - São Paulo, SP.

3 Departamento de Nutrição da Faculdade de Saúde Pública - CEP 01246-904, São Paulo, SP. Corresponding author: karenmarianne@usp.br

Suggested citation: Caldeira KMS, et al. Overweight and its relationship with duration of breastfeeding in preschoolers. Journal of Human Growth and Development. 25(1): 89-96

Manuscript submitted Oct 08 2014, accepted for publication Feb 222015. 
characteristics which exert an influence on the development of obesity ${ }^{1}$.

Another variable which may be involved with overweight in childhood is birth weight, considering both high $(>4000 \mathrm{~g})$ and low $(<2500 \mathrm{~g})$ birth weights. However, findings in the literature by studies assessing this relationship remain conflicting ${ }^{5}$.

With regard to breastfeeding, its role in preventing undernutrition and reducing infant mortality is well established ${ }^{6}$. Kramer $^{7}$ was one of the first to raise the question over the link between obesity and breastfeeding, and commenced studies investigating this issue. In his study among adolescents, a protective relationship against obesity of longer breastfeeding and delayed introduction of solid foods in child feeding was identified.

Current recommendations indicate exclusive breastfeeding for the first six months of life followed by complements to breastfeeding thereafter for the first two years of life ${ }^{\text {. }}$.

However, the WHO estimates that under $40 \%$ of infants globally are exclusively breastfed up to the sixth month of life ${ }^{8}$.

Following the Kramer study, other authors investigated the subject based on nutritional assessments of different groups of individuals, although results remain conflicting 9,10,11.

Several theories attempt to explain the mechanism of action for the protective effect of breastfeeding against obesity. Researchers have suggested two putative mechanism which may be involved in the protective relationship between breastfeeding and obesity ${ }^{12,13}$ :

-development of intake control by the infant: in breastfeeding the child determines when it is full and refuses the food, whereas in the use of infant formulas, the feeder may encourage higher consumption.

- metabolic changes as a result of breastfeeding: studies have shown higher sera levels of insulin, responsible for fat storage in adipocytes, in breastfed children than those fed infant formulas. This increase in sera insulin level may be related to the protein concentration in milk formulas given to the child.

Another theory which has been the focus of studies in recent decades is that of metabolic imprinting. This is defined as the effect of events which occur in early life and their future physiological impact. Thus, feeding is one such event, being associated with future health parameters ${ }^{14}$.

Nevertheless, all theories seeking to explain the relationship of breastfeeding with obesity and their respective mechanisms require further, more specific investigations to obtain more precise results ${ }^{10,11,14}$.

Therefore, the objective of the present study was to investigate the prevalence of overweight and determine its relationship with breastfeeding in preschoolers.

\section{METHOD}

A cross-sectional study in children aged 4860 months from a city in the State of Gerais, Brazil, located $276 \mathrm{~km}$ from the capital Belo Horizonte, was carried out.

The city chosen has, according to the 2010 Census, a population of 8,165 inhabitants, $76 \%$ of whom live in the urban area, $20.5 \%$ in the rural area while approximately 200 inhabitants are children aged 48-60 months attending preschools $^{15}$.

In 2010, the municipal human development index (MHDI) was 0.71 , indicating high human development ( 0.7 to 0.799$)^{16}$.

The study was run within six schools situated in the urban and rural areas of the city, and all children aged 48-60 months, enrolled at and attending the schools, were asked to take part, giving an initial group of 200 children. Data on the outcome variable of one child could not be collected, thus giving a final study sample of 219 children.

On the same day as collection of the Free and Informed Consent Form and the questionnaires filled out by the children's parents or guardians, the children were submitted to the anthropometric assessment. Parents or guardians who had problems filling in the questionnaire were assisted by the researcher.

Socioeconomic and demographic data on the mothers or guardians were collected along with data on previous and current feeding of the child. Regarding current feeding habits, questions were asked on the food groups included in the recommendations of the dietary guide "Ten steps healthy eating for children over 2 years of age"17.

Anthropometric variables used in the study were weight and height, both collected in duplicate by the researcher, recorded in the questionnaire for the child and subsequently used to calculate body mass index (BMI).

Digital solar scales (model 1632 by Tanita ${ }^{\circledR}$ ) with a capacity of $150 \mathrm{~kg}$ and graduations every $200 \mathrm{~g}$ was used. A portable stadiometer (model bodymiter 208 by $\mathrm{Seca}^{\circledR}$ ) with a capacity of $2 \mathrm{~m}$ and graduations every $0.1 \mathrm{~cm}$ was also employed. Use of these devices in the study was granted by the Laboratory of Nutritional Assessment of Populations.(LANPOP) of the University of São Paulo School of Public Health.

The outcome variable was defined as the nutritional diagnosis of weight of the children, classified under two categories: overweight and absence of overweight. To define this variable, the 2006 parameters of the World Health Organization recommended by the Ministry of Health for children aged $0-5$ years were used ${ }^{18}$. The weight and height measurements were used to calculate body mass index (BMI), classified according to z-score. Subjects with Z-score $>+2$ were considered overweight and with $<+2$ classified in the absence of overweight category.

The explanatory variables were analyzed to assess their relationship with nutritional status of the children. Breastfeeding was considered the main variable whereas the control variables comprised the remaining information on the child and their parents, in addition to socioeconomic data.

For the child, the following categorized variables were analyzed: exclusive breastfeeding 
(never, up to 1 month, up to 4 months, up to 6 months or longer), complemented breastfeeding (never, up to 6 months, up to 12 months, for over 12 months), birth weight (low weight $-<2500 \mathrm{~g}$, normal weight - 2500g-3999g, macrosomia - $\mathrm{e}^{\prime \prime}$ 4000g, sex (male, female) and current feeding, considering the food groups sugars, fats, greens/ vegetables, fruit and soft drinks.

Consumption of the selected food groups was analyzed based on frequency: consumed 0-2 times per week; consumed 3 times per week; consumed every day of the week.

In relation to the family, the following variables were assessed: maternal age (continuous); maternal schooling (never studied, studied up to primary level, up to secondary, or up to higher education level or greater); area of residence (urban or rural); maternal nutritional status according to the WHO for adults ${ }^{18}$ (low weight - BMI<18.5kg/m², eutrophic - BMI 18.5-24.9 kg/ $\mathrm{m}^{2}$, overweight - BMI $\left.>25 \mathrm{~kg} / \mathrm{m}^{2}\right)$; maternal working at birth of child (no, yes); current maternal working (no, yes).

Data were expressed as proportions, measures of central tendency and of dispersion (medians, means and standard deviation). The analysis of the relationship between outcome and the explanatory variables was performed using logistic regression. Initially, the relationship between the nutritional diagnosis of the preschoolers and main explanatory variables exclusive breastfeeding (EBF), and complemented breastfeeding (CBF) was assessed separately using simple logistic analysis.

Subsequently, the relationship between each of the remaining explanatory control variables and the outcome was explored by simple Poisson regression, where each independent variable was analyzed with outcome. All the explanatory variables analyzed with a p-value $d^{\prime \prime} 0.20$ were submitted in conjunction to multiple Poisson regression, comprising two models. The first with EBF as the main variable plus the other variables (model 1 ) and a second model with the variable CBF plus remaining variables (model II). Since EBF and CBF were main variables, these were input into the models for any $p$-value. The use of Poisson regression with robust variance allows obtention of a good estimate for prevalence ratio.

In order to determine the association between the explanatory and outcome variables, a level of significance of $5 \%$ was adopted.

The study was submitted to the Ethics Committee of the School of Public Health and of the local institutions and approved in November 2011. The free and informed consent form was signed by the parents or guardians of the preschoolers who participated in the study.

\section{RESULTS}

The prevalence of overweight in the children assessed was $9.6 \%(z$-score $>+2)$ and exclusive breastfeeding for 6 months or longer was a protective factor against overweight in childhood.
Table 1 shows the distribution of the children according to demographic indicators, birth weight and current nutritional classification, revealing a slight predominance of males.

A high proportion of the children studied had never been exclusively breastfed. Low rates were found for total duration of breastfeeding up to 12 months and over 12 months and likewise for exclusive breastfeeding for 6 months or longer.

Data on maternal nutritional classification showed that $46.0 \%$ were overweight (BMI e"25kg/ $\mathrm{m}^{2}$ ). Regarding maternal working, it was found that the proportion of mothers working at the time of birth of the child was much lower than the mothers currently working. Among those mothers working at the birth of the child, the mean age of the child upon the mother's return to work was 4.99 months ( $S D \pm 2.81$, minimum 0.5 and maximum 18 months).

Maternal age ranged from 17 to 40 years with a mean of 30.2 years (SD \pm 6.63 ) and average maternal schooling was 8 years $(S D \pm 3.52)$, ranging from 0 to15 years.

The current frequency of consumption of certain food groups at the children's homes is given in Table 2, which shows a low intake of fruit and vegetables/greens and high consumption of soft drinks and sweet products.

Table 3 depicts the distribution of children according to breastfeeding and nutritional classification, together with the results of the simple logistic regression of EBF, CBF and outcome.

Analysis of the relationship of the main independent variable, exclusive breastfeeding, comparing exposure categories with children who had never been exclusively breastfed by their mothers, revealed a tendency for association of EBF for 6 months or longer with outcome, although this was not statistically significant. No such association was found for CBF.

Tables $\mathbf{4}$ and $\mathbf{5}$ show the results of the simple Poisson regressions. The variables having categories with $p<0.20$ were: consumption of soft drink 3 times per week, of fruit 3 times per week, and of snacks 1 or more times per week (risk for overweight), as well as the variable maternal nutritional classification which showed an association of maternal overweight with overweight in the children.

The two final multiple Poisson regression models, one whose main variable was EBF (model I) and the other whose main variable was CBF (model II), are shown in Tables 6 and 7, respectively.

In Table 6, exclusive breastfeeding is positively associated with the absence of overweight in childhood on the last of the three categories analysed (EBF for 6 months or longer). Table 7 however, reveals that complemented breastfeeding did not share the same result.

Considering the explanatory control variables on both final models, consumption of snacks once or more per week was associated with the presence of overweight in childhood. 
Table 1: Distribution of sample, according to the explanatory variables: child (sex, area of residence, birth weight and current nutritional classification), main (exclusive and complemented breastfeeding) and maternal (nutritional classification, working at birth of child, current working and schooling), of children aged 48-60 months from a city in Minas Gerais, 2011

\begin{tabular}{|c|c|c|}
\hline Variable & $\mathbf{N}$ & $\%$ \\
\hline \multicolumn{3}{|l|}{ Sex } \\
\hline Male & 115 & 52.5 \\
\hline Female & 104 & 47.5 \\
\hline \multicolumn{3}{|l|}{ Area of residence } \\
\hline Urban & 175 & 79.9 \\
\hline Rural & 44 & 20.1 \\
\hline \multicolumn{3}{|l|}{ Birth weight* } \\
\hline$<2500 \mathrm{~g}$ & 13 & 6.1 \\
\hline 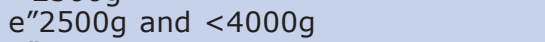 & 185 & 86.9 \\
\hline $\mathrm{e}^{\prime \prime} 4000 \mathrm{~g}$ & 15 & 7 \\
\hline \multicolumn{3}{|l|}{ Nutritional classification* } \\
\hline Absence of overweight (z-score d"2) & 198 & 90.4 \\
\hline Overweight (z-score $>2$ ) & 21 & 9.6 \\
\hline \multicolumn{3}{|l|}{ Exclusive breastfeeding* } \\
\hline Never & 41 & 18.8 \\
\hline Up to 1 month & 19 & 8.7 \\
\hline Up to 4 months & 88 & 40.4 \\
\hline Up to 6 months or longer & 70 & 32.1 \\
\hline \multicolumn{3}{|c|}{ Exclusive complemented breastfeeding* } \\
\hline Never & 38 & 17.5 \\
\hline Up to 6 months & 74 & 34.1 \\
\hline Up to 12 months & 37 & 17.1 \\
\hline Over 12 months & 68 & 31.3 \\
\hline \multicolumn{3}{|l|}{ Maternal nutritional classification* } \\
\hline Malnourished & 5 & 2.4 \\
\hline Eutrophic & 110 & 51.6 \\
\hline \multirow{2}{*}{\multicolumn{3}{|c|}{ Maternal working at birth of child* }} \\
\hline & & \\
\hline Yes & 96 & 44.4 \\
\hline No & 120 & 55.6 \\
\hline \multicolumn{3}{|l|}{ Current maternal working* } \\
\hline Yes & 161 & 74.5 \\
\hline No & 55 & 25.5 \\
\hline \multicolumn{3}{|l|}{ Maternal Schooling* } \\
\hline Never & 2 & 0.9 \\
\hline Primary education & 119 & 55.1 \\
\hline Secondary education & 73 & 33.8 \\
\hline Higher education or greater & 22 & 10.2 \\
\hline
\end{tabular}

* Sum of children studied is under 219 due to missing answer for the variable in question.

Table 2: Distribution of sample, according to current food frequency and consumption of children aged 48-60 months from a City in Minas Gerais, 2011

$\begin{array}{lcc} & \mathbf{N} & \text { \% } \\ \text { Fruit consumption } & & 4.6 \\ \text { Never } & 10 & 23.7 \\ 1 \text { to 2 times per week } & 52 & 26.9 \\ 3 \text { times per week } & 59 & 44.8 \\ \text { Every day of the week } & 98 & 16.9 \\ \text { Vegetable and legume consumption } & 37 & 19.6 \\ \text { Never } & 43 & 21.5 \\ 1 \text { to 2 times per week } & 47 & 42.0 \\ 3 \text { times per week } & 92 & 15.1 \\ \text { Every day of the week } & 33 & 53.2 \\ \text { Neft drinks consumption } & 116.7 \\ 1 \text { to 2 times per week } & 43 & 11.9 \\ 3 \text { times per week } & 26 & 45.4 \\ \text { Every day of the week } & & 44.5 \\ \text { Unhealthy snack consumption* } & 99 & 6.9 \\ \text { Never } \text { to 2 times per week } & 97 & 3.2 \\ 3 \text { times per week } & 15 & 5.5 \\ \text { Every day of the week } & 7 & 31.2 \\ \text { Nevet product consumption } & & 27.1 \\ 1 \text { to 2 times per week } & 12 & 36.2 \\ 3 \text { times per week } & 68 & \end{array}$

* Sum of children studied is under 219 due to missing answer for the variable 
Table 3: Distribution and prevalences (\%) of z-score $d^{\prime \prime}$ or $>2$, Prevalence Ratios (PR) and Confidence Intervals ( $95 \% \mathrm{CI})$, according to the presence of exclusive and complemented Breastfeeding of children aged 48-60 months from a city in Minas Gerais, 2011

\begin{tabular}{|c|c|c|c|c|c|c|c|c|c|c|}
\hline \multirow[t]{2}{*}{ Variable } & \multicolumn{2}{|c|}{$z$-score $\leq \mathbf{2}$} & \multicolumn{2}{|c|}{ z-score $>2$} & \multicolumn{2}{|c|}{ Total } & \multirow[t]{2}{*}{$P R$} & \multirow[t]{2}{*}{$5 \%$} & \multirow[t]{2}{*}{ CI } & \multirow[t]{2}{*}{$\mathbf{P}$} \\
\hline & $\mathbf{N}$ & $\%$ & $\mathbf{N}$ & $\%$ & $\mathbf{N}$ & $\%$ & & & & \\
\hline \multicolumn{11}{|c|}{ Exclusive breastfeeding } \\
\hline Never (reference) & 35 & 85.4 & 6 & 14.6 & 41 & 100 & 1 & - & - & - \\
\hline Up to 1 month & 18 & 94.7 & 1 & 5.3 & 19 & 100 & 0.36 & 0.05 & 2.80 & 0.328 \\
\hline Up to 4 months & 77 & 87.5 & 11 & 12.5 & 88 & 100 & 0.85 & 0.34 & 2.15 & 0.738 \\
\hline 6 months or longer & 67 & 95.7 & 3 & 4.3 & 70 & 100 & 0.29 & 0.08 & 1.11 & 0.071 \\
\hline Total & 197 & 90.4 & 21 & 9.6 & 218 & 100 & - & - & - & - \\
\hline \multicolumn{11}{|c|}{ Complemented breastfeeding } \\
\hline Never (reference) & 33 & 86.8 & 5 & 13.2 & 38 & 100 & 1 & - & - & - \\
\hline Up to 6 months & 67 & 90.5 & 7 & 9.5 & 74 & 100 & 0.72 & 0.24 & 2.12 & 0.550 \\
\hline Up to 12 months & 32 & 86.5 & 5 & 13.5 & 37 & 100 & 1.03 & 0.32 & 3.27 & 0.964 \\
\hline Over 12 months & 64 & 94.1 & 4 & 5.9 & 68 & 100 & 0.45 & 0.13 & 1.57 & 0.209 \\
\hline Total & 196 & 90.3 & 21 & 9.7 & 217 & 100 & - & - & - & - \\
\hline
\end{tabular}

Table 4: Prevalence Ratios (PR) and Confidence Intervals (95\% CI), according to birth weight, area of residence and current frequency of consumption of food groups of children aged 48-60 months from a city in Minas Gerais, 2011

\begin{tabular}{|c|c|c|c|c|}
\hline Variable & $P R$ & $95 \%$ & CI & $\mathbf{P}$ \\
\hline \multicolumn{5}{|l|}{ Birth weight } \\
\hline$<2500 \mathrm{~g}$ (reference) & 1 & - & - & - \\
\hline$>2500 \mathrm{~g} a<4000 \mathrm{~g}$ & 1,12 & 0,16 & 7,36 & 0,906 \\
\hline$>4000 \mathrm{~g}$ & 2,47 & 0,30 & 19,90 & 0,394 \\
\hline \multicolumn{5}{|l|}{ Area of residence } \\
\hline Urban area (reference) & 1 & - & - & - \\
\hline Rural area & 0,66 & 0,20 & 2,15 & 0,494 \\
\hline \multicolumn{5}{|c|}{ Vegetable and legume consumption } \\
\hline Never (reference) & 1 & - & - & - \\
\hline 1 to 2 times per week & 0,86 & 0,18 & 4,02 & 0,849 \\
\hline 3 times per week & 1,57 & 0,42 & 5,89 & 0,500 \\
\hline Every day of the week & 1,21 & 0,34 & 4,22 & 0,769 \\
\hline \multicolumn{5}{|l|}{ Fruit consumption } \\
\hline 1 to 2 times per week (reference) & 1 & - & - & - \\
\hline \multicolumn{5}{|l|}{3 times per week } \\
\hline Every day of the week & 2,80 & 0,78 & 10,08 & 0,115 \\
\hline \multicolumn{5}{|l|}{ Unhealthy snack consumption } \\
\hline Never (reference) & 1 & - & - & - \\
\hline 1 or more times per week & 3,53 & 1,29 & 12,19 & 0,016 \\
\hline \multicolumn{5}{|l|}{ Soft drinks consumption } \\
\hline Never (reference) & 1 & - & - & - \\
\hline 1 to 2 times per week & 1,42 & 0,33 & 6,19 & 0,639 \\
\hline 3 times per week & 2,68 & 0,59 & 12,13 & 0,199 \\
\hline Every day of the week & 1,27 & 0,19 & 8,44 & 0,805 \\
\hline \multicolumn{5}{|l|}{ Sweet product consumption } \\
\hline Never (reference) & 1 & - & - & - \\
\hline 1 to 2 times per week & 1,58 & 0,22 & 11,47 & 0,647 \\
\hline 3 times per week & 1,02 & 0,13 & 7,98 & 0,987 \\
\hline Every day of the week & 0,91 & 0,12 & 6,96 & 0,929 \\
\hline
\end{tabular}

Table 5: Prevalence Ratios (PR) and Confidence Intervals ( $95 \% \mathrm{CI}$ ), according to maternal characteristics of children aged 48-60 months from a city in Minas Gerais, 2011

\begin{tabular}{|c|c|c|c|c|}
\hline Variable & $\boldsymbol{P R}$ & $95 \%$ & CI & $\mathbf{P}$ \\
\hline $\begin{array}{l}\text { Maternal Age } \\
\text { Maternal Schooling }\end{array}$ & 1.00 & 0.95 & 1.07 & 0.824 \\
\hline Never studied or studied up to primary level (reference) & 1 & - & - & - \\
\hline Studied up to Secondary level & 0.51 & 0.17 & 1.51 & 0.224 \\
\hline \multicolumn{5}{|l|}{ Maternal working at birth of child } \\
\hline Yes (reference) & 1 & - & - & - \\
\hline No & 0.80 & 0.35 & 1.85 & 0.601 \\
\hline \multicolumn{5}{|l|}{ Current maternal working } \\
\hline Yes (reference) & 1 & - & - & - \\
\hline No & 0.52 & 0.16 & 1.70 & 0.277 \\
\hline \multicolumn{5}{|l|}{ Maternal nutritional classification } \\
\hline Malnourished to eutrophic weight (reference) & 1 & - & - & - \\
\hline Overweight & 1.91 & 0.82 & 4.42 & 0.132 \\
\hline
\end{tabular}


Table 6: Final Poisson multiple regression model I according to categories of exclusive breastfeeding, consumption of fruit, fried food, snacks and soft drinks and maternal nutritional classification of children aged 48-60 months from a city in Minas Gerais, 2011

\begin{tabular}{|c|c|c|c|c|}
\hline Variable & $P R$ & $95 \%$ & CI & $\mathbf{P}$ \\
\hline \multicolumn{5}{|l|}{ Exclusive breastfeeding } \\
\hline Never (reference) & 1 & - & - & - \\
\hline Up to 1 month & 0.31 & 0.05 & 1.85 & 0.198 \\
\hline Up to 4 months & 0.65 & 0.27 & 1.56 & 0.337 \\
\hline Up to 6 months or longer & 0.25 & 0.07 & 0.90 & 0.034 \\
\hline \multicolumn{5}{|l|}{ Fruit consumption } \\
\hline 0 to 2 times per week (reference) & 1 & - & - & - \\
\hline 3 times per week & 2.72 & 0.77 & 9.56 & 0.119 \\
\hline Every day of the week & 1.88 & 0.57 & 6.20 & 0.300 \\
\hline \multicolumn{5}{|l|}{ Snack consumption } \\
\hline Never (reference) & 1 & - & - & - \\
\hline 1 or more times per week & 3.11 & 1.10 & 8.73 & 0.032 \\
\hline \multicolumn{5}{|l|}{ Soft drinks consumption } \\
\hline Never (reference) & 1 & - & - & - \\
\hline 1 to 2 times per week & 1.21 & 0.29 & 5.06 & 0.796 \\
\hline 3 times per week & 1.85 & 0.42 & 8.14 & 0.414 \\
\hline Every day of the week & 1.08 & 0.19 & 6.20 & 0.927 \\
\hline \multicolumn{5}{|l|}{ Maternal nutritional classification } \\
\hline Malnourished to eutrophic weight (reference) & 1 & - & - & - \\
\hline Overweight & 1.80 & 0.80 & 4.05 & 0.154 \\
\hline
\end{tabular}

Table 7: Final Poisson multiple regression model II according to categories of complemented breastfeeding, consumption of fruit, fried food, snacks and soft drinks and maternal nutritional classification of children aged 48-60 months from a city in Minas Gerais, 2011

\begin{tabular}{|c|c|c|c|c|}
\hline Variable & $P R$ & $95 \%$ & CI & $\mathbf{P}$ \\
\hline \multicolumn{5}{|l|}{ Complemented breastfeeding } \\
\hline Never (reference) & 1 & - & - & - \\
\hline Up to 6 months & 0.67 & 0.23 & 1.93 & 0.460 \\
\hline Up to 12 months & 0.94 & 0.30 & 3.01 & 0.923 \\
\hline For 12 months or longer & 0.38 & 0.11 & 1.34 & 0.133 \\
\hline \multicolumn{5}{|l|}{ Fruit consumption } \\
\hline 0 to 2 times per week (reference) & 1 & - & - & - \\
\hline 3 times per week & 2.47 & 0.69 & 8.88 & 0.166 \\
\hline Every day of the week & 1.77 & 0.52 & 6.05 & 0.360 \\
\hline \multicolumn{5}{|l|}{ Snack consumption } \\
\hline Never (reference) & 1 & - & - & - \\
\hline 1 or more times per week & 3.12 & 1.08 & 9.01 & 0.035 \\
\hline \multicolumn{5}{|l|}{ Soft drinks consumption } \\
\hline Never (reference) & 1 & - & - & - \\
\hline 1 to 2 times per week & 1.40 & 0.30 & 6.44 & 0.666 \\
\hline 3 times per week & 2.19 & 0.47 & 10.14 & 0.316 \\
\hline Every day of the week & 1.09 & 0.17 & 6.85 & 0.925 \\
\hline \multicolumn{5}{|l|}{ Maternal nutritional classification } \\
\hline Malnourished to eutrophic weight (reference) & 1 & - & - & - \\
\hline Overweight & 1.87 & 0.83 & 4.23 & 0.134 \\
\hline
\end{tabular}

\section{DISCUSSION}

In the population studied, $82.49 \%$ of mothers reported breastfeeding their infant for some period, with the percentage breastfeeding for up to 12 months and over 12 months standing at $17.05 \%$ and $31.34 \%$, respectively. Only $32.11 \%$ of the infants were exclusively breastfed for the first six months as recommended ${ }^{20}$.

The rates found were lower than those reported in Brazil by the latest surveys, the PNDS (National Survey on Demography and Health) (2006) and Second Survey of Prevalence of Breastfeeding in Brazilian Capitals and Federal District (2009). The 2006 PNDS identified a rate of
$38.6 \%$ exclusive breastfeeding for the first 6 months whereas the second survey found prevalences of $41 \%$ and $58.7 \%$ for EBF up to 6 months and for CBF for ages of 9-12 months, respectively ${ }^{2,20}$.

Exclusive breastfeeding for a duration of 6 months or longer was confirmed as a protective factor against obesity in childhood.

In previous studies, many authors have found a positive correlation between breastfeeding and protection against overweight ${ }^{7,10}$. In the present study, this association was found only for EBF, akin to a meta-analysis reviewed ${ }^{11}$.

In a previous study conducted in an adult population, no relationship was found between breastfeeding and overweight. Perhaps this was 
because the population under study (22-23 years) had spent a relatively longer period of their lives influenced by other variables such eating habits and type of physical activity ${ }^{9}$.

Other authors who failed to find any association between breastfeeding and prevention of overweight studied a population aged 4-18 years ${ }^{21}$, and did not consider exclusive breastfeeding in their study, having analyzed only complemented breastfeeding ${ }^{21}$.

For complemented breastfeeding however, no protective relationship against overweight was found. This might be explained by the age groups assessed of 6 months and over, i.e. children already receiving complementary feeding and thus exposed to other variables which could favor weight gain, thereby lessening the influence of breastfeeding.

Besides complementary feeding during the first year of life, another aspect to be considered is the habitual feeding pattern of the child, representing a determinant, together with low energy expenditure, of weight gain in childhood ${ }^{1}$.

According to the latest data from the Family Budget Survey (POF)(2008-2009), there was increased overweight and obesity was evident across virtually all age strata of the Brazilian population, except for the first four years of life, and a greater frequency of consumption of readyprepared foods and processed mixtures plus a lower intake of grains, legumes and vegetables was also observed ${ }^{3,22}$.

In the present study, above-recommended intake of soft drinks and sweet products was seen along with below-recommended intakes of legumes, green vegetables and fruit.

Consumption of snacks once or more per week was identified as a risk factor for overweight in the preschoolers analyzed. These foods are known

\section{REFERENCES}

1. World Health Organization (WHO). Obesity and overweight. What are overweight and obesity? Key Facts. [cited 2013 Jul 11]. Available from: http://www.who.int/mediacentre/factsheets/ fs311/en/

2. Ministério da Saúde. Pesquisa Nacional de Demografia e Saúde da Criança e da Mulher 2006. Brasília-DF: MS; 2009.

3. Instituto Brasileiro de Geografia e Estatística. Pesquisa de Orçamentos Familiares 2008-2009. Aquisição alimentar domiciliar per capita Brasil e grandes regiões. Rio de Janeiro: IBGE; 2010.

4. Medeiros CCM, Cardoso MAA, Pereira RAR, Alves GTA, França ISX, Cora AS, et al. Estado nutricional e hábitos de vida em escolares. Rev Bras Crescimento Desenvolv Hum. 2011; 21(3): 789-797.

5. Rossi CE, Vasconcelos FAG. Peso ao nascer e obesidade em crianças e adolescentes: uma revisão sistemática. Rev Bras Epidemiol. 2010; 13(2): 246-258. Doi: 10.1590/S1415-790X201 0000200007. for their fat-rich composition, particularly saturated fats, and for having a high energy density and salt content, thereby constituting a risk for the development of obesity ${ }^{23}$.

Researchers have noted, based on comparisons of results from the POF surveys for 1987-88, 1995-96 and 2002-03, that the consumption of "ultraprocessed" foods, ready-toeat products such as hamburgers, pizzas, savories and other snacks covered in the survey, has increased significantly in terms of their proportion of total calories consumed by the population, rising from $19.2 \%$ to $21,4 \%$ and to $28 \%$ of total intake, respectively ${ }^{23}$.

However, in the present study, the proportion of children consuming snacks more than three times per week was low. This result may stem from the absence of large fast food chains in the city, limiting the population's access to this type of food ${ }^{24}$.

Birth weight of under $2500 \mathrm{~g}$ or over $4000 \mathrm{~g}$, and likewise maternal variables and nutritional classification and schooling, exhibited no association with overweight in the children.

The results showed that exclusive breastfeeding for six months or longer was associated with absence of overweight and can be considered a protective factor against overweight in children aged 48-60 months. However, the consumption of snacks once or more per week was associated with overweight, and therefore can be considered a risk factor for overweight in childhood.

The prevalence of exclusive and complemented breastfeeding was lower than levels recommended in the literature and below the national average.

6. Passanha A, Cervato-Mancuso AM, Silva MEMP. Elementos protetores do leite materno na prevenção de doenças gastrintestinais e respiratórias. Rev Bras Crescimento Desenvolv Hum. 2010;20(2):251-260.

7. Kramer MS. Do breastfeeding and delayed introduction solid foods protect against subsequent obesity? J Pediatr. 1981; 98(6): 883-887.

8. World Health Organization (WHO). Infant and young child feeding: model Chapter for text books for medical students and allied health professionals. France: WHO ; 2009.

9. Gigante DP, Minten GC, Horta BL, Barros FC, Victora CG. Avaliação nutricional de adultos da coorte de nascimentos de 1982, Pelotas, RS. Rev Saúde Pública. 2008; 42(supl.2): 60-69. Doi: 10.1590/S0034-89102008000900009.

10. Horta BJ, Bahl R, Martines JC, Victora CG. Evidence on long term breastfeeding systematic reviews and meta-analyses. World Health Organization. Geneva: 2007.

11. National Center for Chronic Disease Prevention and Health Promotion - Division of Nutrition and Physical Activity. Does breast feeding 
reduce the risk of pediatric overweight? Atlanta: Centers for Disease Control and Prevention. 2007.

12. Fischer JO, Birch LL, Smiciklas-Wright $H$, Picciano MF. Breastfeeding through the first year predicts maternal control in feeding and subsequent toddler energy intakes. J Am Diet Assoc. 2000; 100(6): 641-46. Doi: 10.1016/ S0002-8223(00)00190-5

13. Gillman MW, Rifas-Shiman SL, Camargo CA, Berkey CS, Frazier AL, Rockett $\mathrm{HRH}$, et al. Risk of overweight among adolescents who were breastfed as infants. JAMA. 2001; 285(19): 2461-67. Doi: 10.1001/jama.285.19.2461.

14. Hanley B, Djane J, Fewtrell M, Grynberg A, Hummel S, Junien C, et al. Metabolic imprinting, programming and epigenetics - a review of present priorities and future. Br J Nutr. 2010; 104(Suppl1): S1-S21. Doi: 10.1017/S000711 4510003338.

15. Instituto Brasileiro de Geografia e Estatística. Censo demográfico 2010 - Capitólio/MG 2010. [cited 2011 Apr 16] Available from: http://www. ibge.gov.br/cidadesat/link.php?uf=mg?

16. Instituto de Pesquisas Econômicas Aplicadas (IPEA). Atlas do Desenvolvimento Humano no Brasil 2013. [cited 2012 Marc 12] Available from: http://www.atlasbrasil.org.br/2013/consulta.

17. Ministério da Saúde. Caderneta da saúde da criança. Brasília-DF: Ministério da Saúde; 2007.
18. Ministério da Saúde. Sistema de Vigilância Alimentar e Nutricional (SISVAN). Curvas de crescimento da Organização Mundial da Saúde. Brasília-DF: Ministério da Saúde; 2009.

19. World Health Organization (WHO). Physical status: the use and interpretation of anthropometry. Geneva: WHO; 1995.

20. Ministério da Saúde. Secretaria de atenção à saúde, Departamento de ações programáticas e estratégicas. II Pesquisa de prevalência de aleitamento materno nas capitais brasileiras e Distrito Federal. Brasília-DF: Ministério da Saúde; 2009.

21. Li L, Parsons TJ, Power G. Breastfeeding in childhood: cross sectional study. BMJ. 2003; 327 (7420): 904-5.

22. Instituto Brasileiro de Geografia e Estatística. Pesquisa de Orçamentos Familiares 2008-2009. Antropometria e estado nutricional de crianças, adolescentes e adultos no Brasil. Rio de Janeiro: IBGE; 2010.

23. Monteiro CA, Levy RB, Claro RM, Castro IRR, Cannon G. Increasing consumption of ultraprocessed foods and likely impact on human health: evidence from Brazil. Public Health Nutr. 2011; 14(1): 5-13. Doi; 10.1017/S136898001 000324

24. Nilsen SJ, Popkin BM. Patterns and trends in food portion sizes 1977-1998. JAMA. 2003; 289(4): 450-453.

\section{RESUMO}

Introdução: a obesidade vem aumentando, de forma expressiva, em crianças e adolescentes. O aleitamento materno tem sido relacionado como fator preventivo de muitas doenças e, nos últimos anos, tem sido verificado seu papel de proteção contra a obesidade na infância. Objetivo: verificar a prevalência de excesso de peso e sua relação com o aleitamento materno em crianças de 48 a 60 meses. Método: estudo transversal, no qual foram coletados dados antropométricos de crianças de 48 a 60 meses, de escolas de Município de Minas Gerais, MG, para cálculo de índice de massa corpórea (IMC) e classificação nutricional. Foram coletados, também, dados sobre a duração do aleitamento materno e alimentação atual da criança, além de variáveis demográficas e socioeconômicas. Excesso de peso foi considerado variável desfecho. A variável explanatória principal foi o aleitamento materno e as variáveis de controle foram alimentação atual e as variáveis demográficas e socioeconômicas. A relação entre o desfecho e as variáveis explanatórias foi verificada por meio de regressão de Poisson. Resultados: a prevalência de crianças com excesso de peso foi de $9,6 \%$. O aleitamento materno exclusivo (AME) até os 6 meses ou mais foi oferecido a 32,11\% das crianças. O estudo aponta uma relação positiva entre a presença de AME e a ausência de excesso de peso em crianças de 48 a 60 meses para a categoria de AME por 6 meses ou mais. Relação semelhante não foi encontrada para o aleitamento materno complementado. Conclusão: A prevalência do excesso peso das crianças do estudo $(9,6 \%)$ foi superior a média nacional $(7 \%)$. 0 aleitamento materno exclusivo por 6 meses ou mais associou-se à ausência de excesso de peso e o aleitamento materno complementado não apresentou associação com o peso das crianças.

Palavras-chave: aleitamento materno, obesidade infantil. 